Journal of Business Management Education | Volume 3, Number 1, May 2018, page. 87-96

\title{
GAMBARAN COOPERATIVE LEARNING TIPE THINK PAIR SHARE UNTUK MENINGKATKAN KEMAMPUAN BERPIKIR KRITIS
}

\author{
Kholidah Hardiyanti Shinta Rukmana \\ Universitas Pendidikan Indonesia \\ kholidah.hardiyanti.shinta@student.edu \\ Dr. H. Hari Mulyadi \\ Universitas Pendidikan Indonesia \\ Harimulyadi@upi.edu \\ Rd. Dian H. Utama \\ Universitas Pendidikan Indonesia \\ Dhutama@upi.edu
}

\begin{abstract}
ABSTRAK
Tujuan - untuk mengetahui penerapan model cooperative learning tipe think pair share untuk kemampuan berpikir kritis siswa.

Desain/metodologi/pendekatan - metode eksperimen dengan quasi eksperimen, Sampel sebanyak 70 peserta didik kelas X Pemasaran dengan menggunakan sampel jenuh. Pengu,pulan data dengan tes pilihan ganda kemampuan berpikir kritis. Analisis data yang digunakan adalah distribusi frekuensi

Temuan Penelitian - peningkatan keterampilan berpikir kritis dengan penerapan model cooperative learning tipe think pair share

Orisinalitas - perbedaan ditemukan dalam objek dan metode penelitian, populasi dan sampel penelitian, periode penelitian, alat ukur dan hasil penelitian, serta mendukung teori serta referensi yang berbeda yang digunakan oleh peneliti sebelumnya.

Kata kunci: Think-Pair-Share, cooperative learning, Berpikir Kritis, Orde Berpikir Tinggi, Efektivitas TPS pada keterampilan berpikir kritis siswa, TPS untuk meningkatkan keterampilan berpikir kritis

Jenis Penelitian : Studi kasus
\end{abstract}

\section{ABSTRAK}

Purpose - This study was conducted to see how application learning model type think pair share to increase critical thinking skills

Design / methodology / approach - This research used experimental method with quasi experiment, Sample of 70 students of Marketing X class using saturated samples. Collection of data with multiple choice test of critical thinking ability. Data analysis used is frequency distribution.

Findings - improving critical thinking skills with the application of cooperative learning type think pair share model Originality - differences were found in research objects and methods, population and sample studies, periods of research, measuring instruments and research results, as well as supporting different theories and references used by previous researchers.repancies found in the object and research methods, population and sample, the study period, measuring tools and research results, as well as the source of theories and foreign journals and books.

Keywords :Think-Pair-Share, cooperative learning, Critical Thinking, High-Order Thinking, Think Pair Share Effectiveness on students' critical thinking skills, Think Pair Share to improve critical thinking skills

Type Article : Research Paper 


\section{PENDAHULUAN}

Pendidikan memiliki peranan penting dalam mencetak sumber daya manusia yang berkualitas dan dapat bersaing di era teknologi (Fatmawati, 2014). Salah satu ciri sumber daya manusia berkualitas memiliki kemampuan berpikir kritis. Artinya berpikir kritis sangat diperlukan dalam berbagai bidang yaitu ekonomi, sosial, politik, budaya, lingkungan dan segala aspek yang berkaitan dalam kehidupan jaman ini (Bashir \& Madhavaiah, 2015).

Dengan demikian, seluruh peserta didik, perlu dibekali dengan kemampuan berargumentasi, mampu memilih alternatif dalam pemecahan masalah, dan mampu membuat kesimpulan untuk membuat keputusan. Pada jenjang pendidikan kejuruan, pelajar harus melakukan langkah kecil sebelum akhirnya terampil berpikir kritis (high order thinking) (Madan \& Yadav, 2016). Kesulitan memiliki kemampuan berpikir kritis siswa disebabkan karena siswa mengalami hambatan memahami konsep pembelajaran (Goodfellow, 1995). Kemampuan berpikir kritis sangat diperlukan siswa, terutama siswa SMK agar dapat memecahkan masalah, membuat keputusan, mempelajari hal baru yang selalu muncul dalam dunia kerja (Haghparast, Nasaruddin, \& Abdullah, 2014).

Penelitian mengenai berpikir kritis telah dilakukan pada tingkat pendidikan di provinsi Jawa Barat seperti Galbreath (Alpusari \& Putra, 2015). Eksperimen menunjukkan bahwa secara keseluruhan siswa tidak memiliki disposisi positif untuk berpikir kritis meskipun mereka menunjukkan tanda-tanda yang menjanjikan dalam beberapa bidang ilmu. Mengemukakan bahwa pada modal intelektual, khususnya kecakapan berpikir tingkat tinggi (higher order thinking) terutama berpikir kritis, merupakan kebutuhan bagi tenaga kerja yang handal. Rangkuman penelitian (Chell, 2013) berasal dari kebutuhan untuk siswa untuk belajar tidak hanya materi pelajaran melalui Model pengajaran konvensional di kelas, tetapi juga meningkatkan daya nalar melalui pengalaman terkait baik secara langsung ke tempat kerja yang sebenarnya atau erat meniru nyata dunia usaha (Bustami \& Corebima, 2017).

Kemampuan berpikir kritis sebagai indikator berpikir tingkat tinggi belum dimiliki sepenuhnya oleh peserta didik, hal tersebut terbukti dalam hasil tes awal untuk mengetahui seberapa besar kemampuan berpikir kritis ditunjukkan dari hasil belajar kognitif. Hasil observasi di SMKN 3 Kota Bandung, terkait dengan hasil belajar kognitif pada mata pelajaran Strategi Pemasaran yang diperoleh pada mata pelajaran strategi pemasaran yang diajarkan di kelas $\mathrm{X}$ SMKN 3 Bandung masih rendah. Hal tersebut terlihat dari data tabel dengan jumlah peserta didik yang lulus melebihi kriteria ketuntasan minimal (KKM), hanya sekitar 15 orang dari 65 peserta didik kelas X PM1 dan X PM2 atau sebesar $22,67 \%$ sedangkan yang kurang dari kriteria ketuntasan minimal mencapai 81 orang dari 65 peserta didik atau sebesar 77,33\%.

Metode pembelajaran Think-Pair-Share merupakan salah satu tipe model pembelajaran kooperatif, yang memungkinkan interaksi antara mahasiswa dengan mahasiswa, mahasiswa dengan dosen; dalam memecahkan suatu masalah (Alpusari \& Putra, 2015). Model pembelajaran ini didisain agar mahasiswa dapat berdiskusi dengan temannya dalam kelompok kecil. Terkait dengan manfaat model pembelajaran TPS, (Ayad, 2010) mengemukakan bahwa: 1) memungkinkan mahasiswa untuk bekerja sendiri dan bekerjasama dengan orang lain; 2) mengoptimalkan partisipasi mahasiswa; 3) memberi kesempatan kepada mahasiswa untuk menunjukkan partisipasi mereka kepada orang lain. Selanjutnya,(Ali, 2016) menambahkan bahwa dalam kegiatan ini diharapkan terjadi pengkonstruksian pengetahuan secara integratif. Peserta dapat menemukan struktur dari pengetahuan yang dipelajarinya (Arsal, 2015).

\section{KAJIAN PUSTAKA}

Belajar merupakan proses manusia untuk mencapai berbagai macam kompetensi, keterampilan, dan sikap. Usaha untuk mencapai kepandaian atau ilmu merupakan usaha manusia untuk memenuhi kebutuhannya, mendapatkan ilmu atau kepandaian yang belum dipunyai sebelumnya (Bahr, 2010). Pandangan tentang pendidikan menggambarkan sekolah seharusnya mencerminkan masyarakat yang lebih besar dan kelas merupakan laboratorium untuk pemecahan masalah kehidupan nyata John Dewey dalam (Baron, 1993).Dewey menganjurkan guru untuk mendorong peserta didik terlibat dalam proyek atau tugas berorientasi masalah dan membantu mereka menyelidiki masalah-masalah tersebut.

Belajar berhubungan dengan perubahan tingkah laku seseorang terhadap sesuatu situasi tertentu yang disebabkan oleh pengalamannya yang berulang-ulang dalam suatu situasi.Usaha untuk mencapai ilmu merupakan usaha manusia untuk memenuhi kebutuhannya, mendapatkan ilmu atau kepandaian yang belum dipunyai sebelumnya (Decd, 2017). Sehingga dengan belajar manusia menjadi tahu, memahami, mengerti, dapat melaksanakan dan memiliki tentang sesuatu. Dalam keseluruhan proses pendidikan di sekolah kegiatan belajar mengajar merupakan kegiatan paling pokok. Hal ini berarti bahwa keberhasilan atau tidaknya pencapaian tujuan 
pendidikan bergantung pada proses belajar yang dilakukan siswa sebagai anak didik.

Teori belajar yang melandasi dalam penelitian adalah teori konstruktivisme. Pembelajaran inovatif yang berlandaskan paradigm konstrutivistik dapat membantu peserta didik untuk mengimplementasi, membentuk kembali atau mentranformasi informasi maupun masalah. Konstruktivisme yang menekankan bahwa pengetahuan dibentuk oleh siswa yang sedang belajar, dan teori perubahan konsep yang menjelaskan bahwa siswa mengalami perubahan konsep terus menerus, sangat berperan dalam menjelaskan mengapa seorang siswa bisa salah mengerti dalam menangkap suatu konsep yang ia pelajari(Tarmedi \& Asri, n.d.).

Teori perkembagan kognitif Piaget yang mewakili konstruktivisme memandang perkembagan kognitif sebagai proses dimana anak aktif membangun sistem makna dan pemahaman realitas melalui pengalaman dan interaksi peserta didik (Thahara, Indonesia, Mulyadi, Indonesia, \& Indonesia, 2016). Pandangan Vygotsky yaitu teori kontruktivisme melalui scaffolding atau pemberian bantuan kepada peserta didik dalam tahap awal perkembangan serta mengurangi bantuan untuk memberikan tanggung jawab yang besar segera setelah peserta didik dapat melakukannya.

Teori belajar tersebut berkenaan dengan kesiapan anak untuk belajar, yang dikemas dalam tahap perkembangan intelektual dari lahir hingga dewasa. Setiap tahap perkembangan intelektual yang dimaksud dilengkapi dengan ciri-ciri tertentu dalam mengkonstruksi ilmu pengetahuan. Misalnya, pada tahap sensori motor anak berpikir melalui gerakan atau perbuatan (Tiruneh, Verburgh, \& Elen, 2014). Pemahaman saat menerima informasi dapat mendorong munculnya ide dan menaikkan struktur kognitif yang memungkinkan peserta didik berpikir kembali mengenai ide sebelumnya. Kegiatan berpikir peserta didik termasuk dalam proses pembelajaran berpusat pada peserta didik.

Kegiatan proses berpikir tingkat tinggi yang harus dimiliki siswa dimana siswa mampu merumuskan masalah, memberikan argumen dan melakukan evaluasi merupakan berpikir kritis. Dengan menerapkan keterampilan metakognisi melalui model kooperatif tipe think pair share membuat siswa mampu mengontrol proses berpikirnya (Goodfellow, 1995). Pendekatan pembelajaran kooperatif tipe Think Pair Share merupakan salah satu model pembelajaran yang ada dalam pembelajaran kontekstual.(Chell, 2013), Konsep dari pendekatan pembelajaran cooperative tipe think pair share ini adalah melatih siswa untuk berfikir mandiri dalam sebuah kelompok belajar. dengan model pembelajaran (Ayad, 2010). Think pair share (TPS), peserta didik dituntut lebih aktif yaitu berpikir mandiri (think), kemudian berpasangan atau berdiskusi (pair) dan berbagi dengan semua kelompok di kelas (share) (Bashir \& Madhavaiah, 2015)). Berdasarkan langkah-langkah tersebut, model TPS mempunyai keunggulan dan kelemahan. Keungulan dari model pembelajaran TPS dapat digunakan sebagai acuan untuk dilakukannya penelitian (Baumfield \& Oberski, 1998). Kelebihan lain, yakni mengoptimalkan partisipasi siswa dalam pembelajaran, meningkatkan pengetahuan, meningkatkan daya pikir siswa, siswa dapat meninjau dan memecahkan masalah dari berbagai sudut pandang yang berbeda (Li \& Lam, 2013). Tujuan pembelajaran melatih guru dalam merumuskan permasalahan yang sesuai dengan tingkat kognitif dan menimbulkan rasa penasaran siswa agar tertarik untuk mempelajari dan mencari solusinya (Fax, 2012) dalam kurikulum 2013.

Model pembelajaran sebagai pedoman dalam merencanakan pembelajaran di kelas atau pembelajaran dalam tutorial dan untuk menentukan perangkat-perangkat pembelajaran. Pembelajaran kooperatif adalah strategi pengajaran yang sukses di mana tim kecil, masing-masing dengan siswa dari tingkat kemampuan yang berbeda, menggunakan berbagai aktivitas belajar untuk meningkatkan pemahaman (S. Kagan, n.d.). Think pair share adalah salah satu metode pembelajaran kooperatif dengan memberikan waktu kepada para siswa untuk berpikir dan merespon serta salíng bantu satu sama lain.

Pendekatan pembelajaran kooperatif tipe Think Pair Share merupakan salah satu model pembelajaran yang ada dalam pembelajaran kontekstual.(Chell, 2013) Konsep dari pendekatan pembelajaran cooperative tipe think pair share ini adalah melatih siswa untuk berfikir mandiri dalam sebuah kelompok belajar. dengan model pembelajaran (Ayad, 2010). Think pair share (TPS), peserta didik dituntut lebih aktif yaitu berpikir mandiri (think), kemudian berpasangan atau berdiskusi (pair) dan berbagi dengan semua kelompok di kelas (share) (Baudin \& Villemur, 2009).

1.Think (berpikir secara individual)

Pada tahap think, guru mengajukan suatu pertanyaan atau masalah yang dikaitkan dengan pelajaran, dan siswa diminta untuk berpikir secara mandiri mengenai pertanyaan atau masalah yang diajukan. Pada tahapan ini, siswa sebaiknya menuliskan jawaban mereka, hal ini karena guru tidak da pat memantau semua jawaban siswa setiingga melalui catatan tersebut guru dapat mengetahui jawaban yang harus diperbaiki atau diluruskan di akhir pembelajaran. Dalam menentukan 
batasan vaktu untuk tahap ini, guru harus mempertimbangkan pen getahuan dasar siswa untuk menjawab pertanyaan yang diberikan, jenis dan bentuk pertanyaan yang diberikan,serta jadwal pembelajaran untuk setiap kali pertemuan.

Kelebihan dari tahap ini adalah adanya "think time" atau waktu berpikir yang memberikan kesempatan kepada siswa untuk berpikir men genai jawaban mereka sendiri sebelum pertanyaan tersebut dijawab oleh siswa lain. Selain itu, guru dapat mengurangi masalati dan adanya siswa yang mengobrol karena tiap siswa memiliki tugas untuk dikerjakan sendiri.

2.Pair (berpasangan dengan teman sebangku) Langkah kedua adalah guru meminta para siswa untuk berpasangan dan mendiskusikan mengenal apa yang telab dipikirkan. Interaksi selama periode ini dapat menghasilkan jawaban bersama. Biasanya guru men gizinkan tidak lebih dari 4 atau 5 menit untuk berpasangan. Setiap pasangan siswa saling berdiskusi mengenai hasil jawaban mereka sebelumnya sehingga hasil akhir yang didapat menjadi lebih baik, karena siswa mendapat tambahan informasi dan pemecahan masalah yang lain.

3.Share (berbagi jawaban dengan pasangan lain atau seluruh kelas) Pada langkah terakhir ini guru meminta pasangan-pasangan tersebut untuk berbagi hasil. Pemikiran mereka dengan pasangan lain atau dengan seluruh kelas. Pada langkah ini akan menjadi efektif guru berkeliling kelas dari pasangan satu ke pasangan yang lain, sehingga seperempat atau separuh dari pasangan-pasangan tersebut memperoleh kesempatan untuk melapor langkah ini merupakan penyempurnaan dan Ian langkah-langkah sebelumnya, dalam arti bahwa langkahin, menolong agar semua kelompok menjadi Iebih memahami men genai pemecahan masalah yang diberikan berdasarkan penjelasan kelompok yang lain.

Hal ini juga agar siswa benar-benar mengerti ketika guru memberikan koreksì maupun penguatan di akhir pembelajaran.Ketekunan, semangat dan kemampuan memotivasi diri merupakan salah satu peranan dari kecerdasan emosional yang ada dalam diri seseorang (Goleman, 2002).

Teori (R. Kagan \& Knopf, 2003), kemampuan berpikir kritis terdapat 3 aspek yakni definisi dan klarifikasi masalah, menilai dan mengolah informasi berhubungan dengan masalah, solusi masalah atau membuat kesimpulan dan memecahkan. Melalui model ini diharapkan kemampuan berpikir kritis peserta didik dapat meningkat sehingga nantinya peserta didik memiliki keterampilan dan kecakapan dalam hidup. Hasil pengembangan kemampuan berpikir kritis akan meningkatkan peserta didik untuk mampu mengakses informasi dan definisi masalah berdasarkan fakta dan data akurat.

Berpikir kritis merupakan sebuah kemampuan yang dimiliki setiap orang untuk menganalisis ide atau sebuah gagasan ke arah yang lebih spesifik yang relevan dengan bukti (King, Goodson, \& Rohani, 1998). Kemampuan berpikir kritis sangat diperlukan untuk menganalisis suatu permasalahan sampai pada tahap pencarian solusi sejak usia sekolah dasar (Wibowo, 2006) . Berpikir kritis merupakan sebuah proses aktif, proses dimana seseorang memikirkan berbagai hal secara lebih mendalam, berfokus untuk memutuskan apa yang mesti dipercaya atau dilakukan dengan mendefinisikan permasalahan, menilai dan mengolah informasi berhubungan dengan masalah, dan membuat solusi permasalahan. Proses berpikir dilibatkan berbagai unsur, yakni otak yang sehat, panca indra, informasi sebelumnya, dan adanya fakta (Utama, S, \& Sutarni, 2016). Berpikir kritis memerlukan upaya terus-menerus untuk menganalisis dan mengkaji keyakinan, pengetahuan yang dimiliki, dan kesimpulan yang dibuat, dengan menggunakan bukti-bukti yang mendukung. Salah satu keterampilan berpikir tingkat tinggi (higher order thinking) adalah berpikir kritis (Portal, 2017). Berpikir kritis menggunakan dasar proses berpikir untuk menganalisis argumen dan memunculkan pengetahuan terhadap setiap makna dan interpretasi, mengembangkan pola penalaran yang kohesif dan logis, memahami asumsi dan bias, serta memberikan model penyampaian yang dapat dipercaya, ringkas, dan meyakinkan (Chell, 2013).

Kemampuan berpikir kritis dalam pembelajaran sangat besar peranannya dalam meningkatkan proses dan hasil belajar (Sanjaya Wina, 2006). Selain manfaat kemampuan berpikir kritis dalam pembelajaran juga mempunyai peranan sebagai bekal siswa untuk menghadapi masa depan( Arsal, 2015). Beberapa penelitian membuktikan manfaat kemampuan berpikir kritis dalam pembelajaran maupun sebagai bekal masa depan siswa. Seorang yang berpikir kritis bisa menanyakan pertanyaan yang tepat, mengumpulkan informasi yang relevan, efisien dan kreatif sehingga memungkinkan seseorang untuk menjadi lebih baik dan sukses dalam kehidupan (Bayat, 2004)(Bayat, 2004)(Bayat, 2004)(Bayat, 2004)(Bayat, 2004)(Bayat, 2004)(Bayat, 2004)(Bayat, 2004)(Bayat, 2004)(Bayat, 2004)(Bayat, 2004)

Keputusan, perencanaan, pemecahan masalah, penilaian, tindakan, dan kemampuan manusia berpikir kritis sebagai kemampuan abstrak tidak dapat diamati secara langsung . Untuk dapat mengembangkan kemampuan berpikir kritis di 
sekolah kita harus mengetahui indikator yang mendukung

Indikator berpikir kritis yang digunakan adalah yang dikebangkan oleh Linn \& Grondlund yaitu membandingkan, menghubungkan sebab akibat, memberikan alasan, meringkas, menyimpulkan, berpendapat, mengelompokkan, menciptakan, menerapkan, menganalisis, mensintesis dan mengevaluasi. kemampuan berpikir kritis terdapat 3 aspek yakni definisi dan klarifikasi masalah, menilai dan mengolah informasi berhubungan dengan masalah, solusi masalah atau membuat kesimpulan dan memecahkan. Melalui model ini diharapkan kemampuan berpikir kritis peserta didik dapat meningkat sehingga nantinya peserta didik memiliki keterampilan dan kecakapan dalam hidup. Hasil pengembangan kemampuan berpikir kritis akan meningkatkan peserta didik untuk mampu mengakses informasi dan definisi masalah berdasarkan fakta dan data akurat. Selain itu, peserta didik juga akan mampu menyusun dan merumuskan pertanyaan secara tepat, berani mengungkapkan ide, gagasan serta menghargai perbedaan pendapat. Melalui berpikir kritis peserta didik akan memiliki kesadaran kognitif sosial dan berpartisipasi aktif dalam bermasyarakat.

Kurikulum 2013 yakni berbasis kompetensi; berkomunikasi, berpikir jernih dan kritis, kemampuan mempertimbangkan segi moral suatu permasalahan, kemampuan menjadi warga negara yang efektif, kemampuan mencoba untuk mengerti dan toleran terhadap pandangan yang berbeda, kemampuan hidup dalam masyarakat global, memiliki minat luas mengenai hidup, memiliki kesiapan untuk bekerja, dan memiliki kecerdasan sesuai dengan bakat/minatnya (Risnanosanti, 2009). Untuk itu, satu solusi memperbaiki kelemahan pembelajaran untuk meyahuti tantangan kurikulum 2013, adalah dengan menerapkan model pembelajaran kooperatif (cooperative learning).

Cooperative Learning identik dengan belajar berkelompok atau belajar kooperatif, yang tentu bukan hal baru dalam dunia pendidikan (Plan, 2018). Terbukti Think pair share sebagai solusi untuk meningkatkan kemampuan berpikir kritis juga disampaikan oleh (Meiramova, Cooperation, Education, \& Centre, 2017) "students place a higher value on learning by participating than on learning by being lectured at and receiving information passively". Selain itu Azlina (2010) menyatakan, "Think-Pair-Share is a cooperative learning technique which is said as a multi-mode discussion ycle in which studentslisten to a question or presentation, have time tothink individually, talk with each other in pairs, and finally share responses with the larger group". Menurut Laura dalam keunggulan model pembelajaran kooperatif tipe Think Pair Share yakni mudah untuk diterapkan pada berbagai tingkatan kemampuan berfikir dan dalam setiap kesempatan sehingga dapat diterapkan pada setiap jenjang pendidikan.

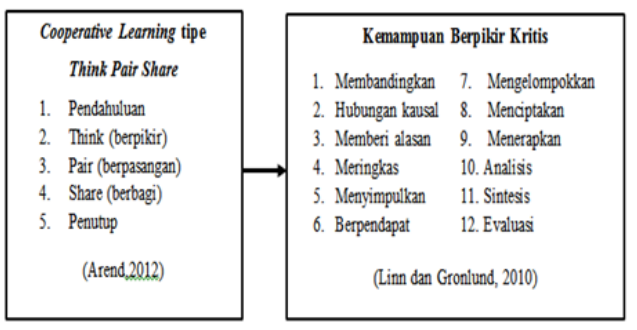

GAMBAR 2

PARADIGMA PENELITIAN

\section{METODE PENELITIAN}

Penelitian ini dilakukan untuk mengetahui penerapan think pair share untuk meningkatkan kemampuan berpikir kritis. Adapun yang menjadi objek penelitian adalah menggunakan think pair share sebagai variabel independent (X). Variabel tersebut dicari bagaimana pengaruhnya terhadap kemampuan berpikir kritis sebagai variabel dependent (Y). Objek yang dijadikan siswa dalam penelitian ini adalah siswa kelas $\mathrm{X}$ SMKN 3 Bandung. Penentuan populasi harus dimulai dengan penentuan secara jelas mengenai populasi yang menjadi sasaran penelitiannya yang disebut populasi sasaran yaitu populasi yang akan menjadi cakupan kesimpulan penelitian. Jadi apabila dalam sebuah hasil penelitian dikeluarkan kesimpulan, maka menurut etika penelitian kesimpulan tersebut hanya berlaku untuk populasi sasaran yang telah ditentukan. Berdasarkan pengertian populasi tersebut maka yang menjadi populasi pada penelitian ini adalah siswa kelas X Pemasaran SMK Negeri 3 Bandung yaitu sebanyak 70 siswa.

Penelitian ini dilakukan untuk mengetahui apakah pembelajaran menggunakan think pair share lebih baik dibandingkan sebelum menggunakan think pair share dalam pelajaran Strategi Pemasaran. Pemecahan masalah dapat diketahui dengan hasil pre-test dan post-test antara kelas yang menggunakan menggunakan think pair share dengan kelas yang menggunakan menggunakan pembelajaran kovensional.Data yang diperoleh dalam penelitian ini penulis menggunakan beberapa teknik penelitian seperti berikut: 1). Studi kepustakaan, yaitu pengumpulan data dengan cara mempelajari buku, makalah, situs website dan majalah guna memperoleh informasi yang berhubungan dengan teori-teori dan konsep-konsep yang berkaitan dengan masalah dan variabel yang diteliti tentang model pembelajaran think pair share dan kemampuan berpikir kritis. 2). 
Studi lapangan, yaitu pengamatan dan peninjauan lapangan terhadap objek yang sedang diteliti yaitu guru dan siswa kelas X Pemasaran SMK Negeri 3 Bandung. Observasi dalam penelitian dimaksudkan untuk mengetahui secara langsung aktivitas duru dan siswa serta menilai kinerja siswa selama proses pembelajaran. 3). Wawancara, tidak terstruktur dimana peneliti tidak menggunakan pedoman wawancara yang telah tersusun secara sistematis dan lengkap untuk pengumpulan datanya. Wawancara dilakukan kepada tim guru bidang studi Strategi Pemasaran SMK Negeri 3 Bandung berkaitan dengan kondisi siswa kelas $\mathrm{X}$ Pemasaran. 4). Instrumen penelitian dalam bentuk tes pilihan ganda. 5). Menurut (Arikunto, 2006) "Tes adalah suatu percobaan yang diadakan untuk mengetahui ada atu tidaknya hasil-hasil pelajaran tertentu pada seorang murid atau kelompok murid".

Adapun tahapan yang dilakukan adalah:

A). Tahap persiapan yang terdiri dari: 1). Telaah mata pelajaran Strategi Pemasaran kelas $X$ 2). Menentukan sekolah yang akan dijadikan tempat penelitian sebagai tempat terjadinya fenomena di lapangan 3). Mengurus surat izin penelitian dan menghubungi pihak sekolah tempat penelitian akan dilaksanakan. 4). Observasi awal, meliputi pengamatan langsung pembelajaran di kelas, wawancara dengan guru dan siswa dan pembelajaran yang biasa dilaksanakan. 5). Perumusan masalah penelitian. 6). Studi literatur terhadap jurnal, buku, artikel dan laporan penelitian mengenai model pembelajaran think pair share. 7). Telaah kurikulum Strategi Pemasaran SMK dan penentuan materi pembelajaran yang dijadikan materi pembelajaran dalam penelitian. Hal ini dilakukan agar pembelajaran yang diterapkan dapat memperoleh hasil akhir sesuai dengan kompetensi dasar yang dijabarkan dalam kurikulum. 8). Menyusun rencana pelaksanaan pembelajaran dan instrument penelitian. 9). Men-judgment instrument (tes) kepada dua orang dosen dan satu guru mata pelajaran kewirausahaan. Instrument ini digunakan untuk tes awal dan tes akhir. 10). Menganalisis hasil uji coba instrument yang meliputi validitas, tingkat kesukaran, daya pembeda dan reliabilitas sehingga layak dipakai untuk tes awal dan tes akhir. 11). Melaksanakan uji coba instrument pada sampel yang memiliki karakteristik sama dengan sampel penelitian. 12). Menganalisis hasil uji coba instrumen yang meliputi validitas, tingkat kesukaran, daya pembeda dan reliabilitas sehingga layak dipakai untuk tes awal dantes akhir.

Tahap Pelaksanaan: 1). Penentuan sampel penelitian yang terdiri dari enam kelas. 2). Penentuan kelas eksperimen dan kelas kontrol. 3) Pelaksanaan tes awal bagi kelas eksperimen dan kelas control. 4)
Memberikan perlakuan berupa pembelajaran pada dua kelas. Pada kelas eksperimen diterapkan model pembelajaran think pair share, sedangkan pada kelas kontrol tidak diterapkan model pembelajaran apapun. 5) Pelaksanaan tes akhir begi kelas eksperimen dan kelas kontrol.

Tahap Akhir: 1) Mengelola data hasil tes awal, tes akhir serta instrument lainnya. 2) Mengelola hipotesis dan membahas temuan penelitian. 3) Menarik kesimpulan.

Model ini juga dianggap memiliki kemantapan untuk memberikan perkiraan informasi yang diperoleh dengan tepat dan mendekati penelitian eksperimen sungguhan yang syarat-syaratnya sulit dipenuhi pada penelitian pendidikan. Dalam desain penelitian ini, terdapat dua kelompok yang terdiri dari kelompok eksperimen dan kelompok kontrol. Kedua kelompok tersebut diberi pre-test untuk mengetahui keadaan awal adakah perbedaan antara kelompok eksperimen dan kelompok kontrol.

Tabel 3

Nonequivalent Control Group Design

\begin{tabular}{cccc}
\hline Group & Pre-test & Treatment & Post-test \\
\hline Eksperimen & $\mathrm{O}_{\mathrm{E} 1}$ & $\mathrm{X}$ & $\mathrm{O}_{\mathrm{E} 2}$ \\
Kontrol & $\mathrm{O}_{\mathrm{K} 1}$ & $\mathrm{Y}$ & $\mathrm{O}_{\mathrm{K} 2}$ \\
\hline (Arikunto, 2010) & & &
\end{tabular}

Keterangan:

$\mathrm{O}_{\mathrm{E} 1} / \mathrm{O}_{\mathrm{K} 1}=$ Tes awal yang diberikan pada siswa.

$\mathrm{X}=$ Pembelajaran dengan think pair share.

$\mathrm{Y} \quad=$ Pembelajaran dengan konvensional

$\mathrm{O}_{\mathrm{E} 2} / \mathrm{O}_{\mathrm{K} 2}=$ Tes akhir yang diberikan pada siswa.

\section{HASIL PENELITIAN DAN PEMBAHASAN}

Berdasarkan hasil hasil pengolahan data yang diambil dari tes yang dilakukan pada kelas eksperimen dengan mengunakan model pembelajaran Cooperative learning tipe Think Pair Share

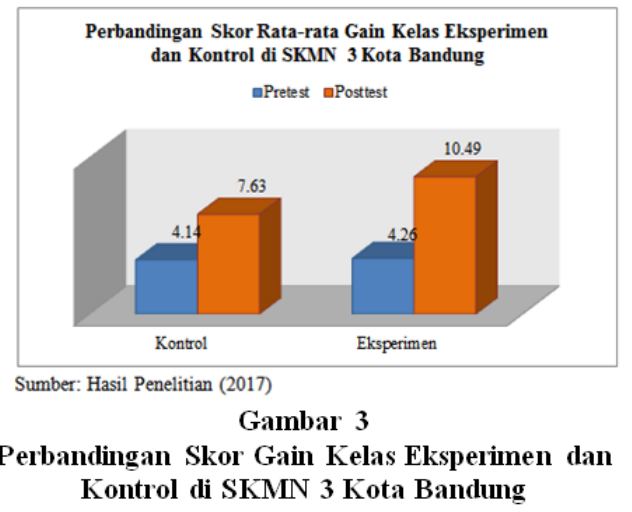

Apabila skor rata-rata pada tiap kelas mengalami kenaikan, otomatis rata-rata tiap indikatornya ikut serta mengalami kenaikan. Terlihat dengan jelas terjadi perubahan baik pada kelas eksperimen yang 
diberi perlakuan dengan model pembelajaran Think Pair Share dan kelas kontrol yang tidak diberi pelakuan model pembelajaran Think Pair Share. Jika kelas kontrol memperoleh nilai rata-rata skor 4,14 pada pretest dan 7,63 pada posttest. Sedangkan kelas eksperimen memperoleh nilai rata-rata skor 4,26 pada pretest dan 10,49 pada posttest. Perubahan rata-rata nilai pada kelas kontrol naik sebanyak 3,49 dari pretest ke posttest. Sementara itu perubahan pada kelas eksperimen naik sebanyak 6,23 dari pretest ke posttest. Maka hasil perbandingan selanjutnya ialah berdasarkan indikatornya.

Tabel 4

Perbandingan Skor Rata-Rata

\begin{tabular}{llcc}
\hline \multicolumn{1}{c}{ Tes } & Keterangan & Eksperimen & Kontrol \\
\hline Pretest & Rata-rata & 87.38 & 35.48 \\
& Terbesar & 100.00 & 75.00 \\
& Terkecil & 50.00 & 8.33 \\
\hline Posttest & Rata-rata & 63.57 & 34.52 \\
& Terbesar & 83.33 & 66.67 \\
& Terkecil & 41.67 & 8.33 \\
\hline Gain & Rata-rata & 0,81 & 0,57 \\
\hline Sumber: Hasil Penelitian (2017) & &
\end{tabular}

Berdasarkan hasil pengolahan data seperti yang telah digambarkan secara umum pada tabel 4.11, maka dapat diketahui bahwa skor rata-rata baik pada kelas eksperimen maupun kelas kontrol mengalami peningkatan. Kelas eksperimen mengalami peningkatan dari rata-rata skor 63.57 menjadi 87.38, artinya setiap peserta didik mengalami peningkatan setelah diterapkannya pembelajaran pembelajaran menggunakan metode Think Pair Share. Sementara rata-rata gain yang diperoleh pada kelas eksperimen sebesar 0,57 dan kelas control sebesar 0,81

Maka dapat diperoleh perbandingan kelas eksperimen dan kontrol pada Gambar 4.3 sebagai berikut:

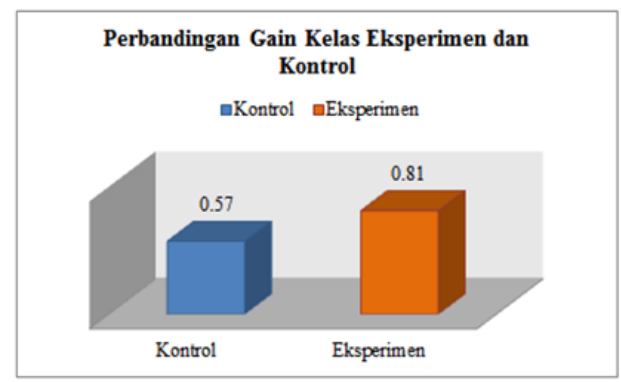

Sumber: Hasil Penelitian (2017)

Gambar 4

Perbandingan Skor Gain Kelas Eksperimen dan Kontrol di SKMN 3 Kota Bandung

Hasil dari pretest secara keseluruhan menunjukkan kelompok kelas eksperimen. Hal ini bisa dilihat dari rata-rata nilai yang diperoleh masingmasing kelompok

Hasil perhitungan dari pengujian rata rata kelas kontrol dan kelas eksperimen secara terperinci sebagai berikut:

\section{Tabel 5}

\section{Hasil Gain Kelas Kontrol}

\begin{tabular}{|c|c|c|c|c|c|}
\hline \multirow{2}{*}{ No } & \multicolumn{4}{|c|}{ Sker Total } & \multirow{2}{*}{ Ket } \\
\hline & Pretest & Postest & Gain & NGain & \\
\hline 1 & 3 & 8 & 3 & 0.60 & Sedang \\
\hline 2 & 1 & 9 & 8 & 0.89 & Tinge \\
\hline 3 & 4 & 8 & 4 & 0.67 & Sedan: \\
\hline 4 & 5 & 8 & 3 & 0.60 & Sedzag \\
\hline 5 & 5 & 9 & 4 & 0.80 & Tinge \\
\hline 6 & 3 & 9 & 6 & 0.86 & Tiaged \\
\hline 7 & 2 & 8 & 6 & 0.75 & Tinge \\
\hline 8 & 1 & 3 & 7 & 0.78 & Tinge \\
\hline 9 & 4 & 9 & 5 & 0.83 & Tinged \\
\hline 10 & 4 & 6 & 2 & 0.33 & Sedas: \\
\hline 11 & 2 & 7 & 5 & 0.63 & Sodang \\
\hline 12 & 4 & 9 & 5 & 0.83 & Tinge \\
\hline 13 & 5 & 8 & 3 & 0.60 & Saduag \\
\hline 14 & 4 & 6 & 2 & 0.33 & Stdus: \\
\hline 15 & 3 & $?$ & 4 & 0.57 & Sedus? \\
\hline 16 & 1 & 7 & 6 & 0.67 & Sedan: \\
\hline 17 & 2 & 7 & 3 & 0.63 & Sedang \\
\hline 18 & 2 & 8 & 6 & 0.75 & Tinge \\
\hline 19 & $?$ & 8 & 1 & 0.33 & Stdan: \\
\hline 20 & 3 & 7 & 4 & 0.57 & Sadang \\
\hline 21 & 2 & 6 & 4 & 0.50 & Sedu: \\
\hline 22 & 4 & 7 & 3 & 0.50 & Sedng \\
\hline 23 & 1 & 7 & 6 & 0.67 & Sedus: \\
\hline 24 & 3 & 6 & 3 & 0.43 & Stdas? \\
\hline 25 & 5 & 5 & 0 & 0.00 & Rendt \\
\hline 26 & 1 & 7 & 6 & 0.67 & Sedun: \\
\hline 27 & 8 & 9 & 1 & 0.50 & Sadang \\
\hline 28 & $?$ & 8 & 1 & 0.33 & Sedus: \\
\hline 29 & 6 & 6 & 0 & 0.00 & Rendx \\
\hline 30 & 6 & 6 & 0 & 0.00 & Rentit \\
\hline 31 & $?$ & 9 & 2 & $0.6 ?$ & Sedasg \\
\hline 32 & 7 & 8 & 1 & 0.33 & Sedus? \\
\hline 33 & 6 & 8 & 2 & 0.50 & Stdus: \\
\hline 34 & 8 & 10 & 2 & 1.00 & Tinge \\
\hline 35 & $?$ & 9 & 2 & 0.67 & Sedun: \\
\hline Jumluh & 145 & 267 & 122 & \multirow{5}{*}{0.57} & \multirow{5}{*}{ Sedus: } \\
\hline $\begin{array}{c}\text { Jomlah Peserta } \\
\text { Didik }\end{array}$ & 35 & 35 & 36 & & \\
\hline Ratarata & 4.14 & 7.63 & 3.49 & & \\
\hline Skot Terbeiar & 8 & 10 & 8 & & \\
\hline Skor Tekecil & 1 & 5 & 0 & & \\
\hline
\end{tabular}

Dari tabel 5, diketahui bahwa hasil analisis gain pada kelas kontrol dapat di kategorikan pada tingkat "sedang", yakni sebesar 0,57. Dari hasil analisis tersebut, diambil simpulan bahwa pembelajaran pada kelas kontrol berpengaruh sedang terhadap kemampuan berpikir kritis, namun hal ini tetap rendah jika dibandingkan dengan kelompok eksperimen. penelitian membuktikan manfaat kemampuan berpikir kritis dalam pembelajaran maupun sebagai bekal masa depan siswa (Ayad, 2010).

Tabel 5

Rekapitulasi Hasil Postest Kelas Kontrol

\begin{tabular}{ccc}
\hline $\begin{array}{c}\text { Kriteria Kemampuan } \\
\text { Berpikir Kritis }\end{array}$ & Frekuensi & Persentase \\
\hline Sangat Rendah & 1 & $2.86 \%$ \\
Rendah & 0 & $0.00 \%$ \\
Sedang & 3 & $8.57 \%$ \\
Tinggi & 14 & $40.00 \%$ \\
Sangat Tinggi & 17 & $48.57 \%$ \\
\hline Jumlah & $\mathbf{3 5}$ & $\mathbf{1 0 0 \%}$ \\
\hline
\end{tabular}


Berdasarkan tabel 5, dapat dilihat mayoritas kemampuan berfikir kritis yakni termasuk dalam kategori sedang. Yang ditunjukkan dengan 19 atau $54.29 \%$ sedangkan minoritas siswa memiliki kemampuan yang sangat rendah.

Tabel 6 Hasil Gain Kelas Eksperimen

\begin{tabular}{|c|c|c|c|c|c|}
\hline \multirow{2}{*}{ No } & \multicolumn{4}{|c|}{ Skor Total } & \multirow{2}{*}{ Ket } \\
\hline & Pretest & Postent & Gain & NGain & \\
\hline 1 & 6 & 10 & 4 & 0.67 & Sodang \\
\hline 2 & 3 & 10 & 3 & 0.71 & Tinge \\
\hline 3 & 6 & 9 & 3 & 0.50 & sadzeg \\
\hline 4 & 1 & 10 & 9 & 0.82 & Tiage \\
\hline 5 & 3 & 9 & 6 & 0.67 & sedxug \\
\hline 6 & 6 & 11 & 5 & 0.83 & Tinge \\
\hline 7 & $s$ & 10 & 5 & 0.71 & Tisa \\
\hline 8 & 4 & 11 & $?$ & 0.88 & Tinge \\
\hline 9 & 5 & 12 & $?$ & 1.00 & Ting \\
\hline 10 & 5 & 10 & 5 & 0.71 & Tinge \\
\hline 11 & 1 & 10 & 9 & 0.82 & Tinge \\
\hline 12 & 5 & 12 & 7 & 1.00 & Tinge \\
\hline 13 & 5 & 12 & 7 & 1.00 & Tinge \\
\hline 14 & 3 & 10 & 7 & 0.78 & Tinge \\
\hline 15 & 1 & 10 & 9 & 0.82 & Tinge \\
\hline 16 & 3 & 11 & 8 & 0.89 & Tinge \\
\hline 17 & 2 & 10 & 8 & 0.80 & Tingei \\
\hline 18 & 3 & 10 & $?$ & 0.78 & Tinge \\
\hline 19 & $?$ & 12 & 5 & 1.00 & Tinge \\
\hline 20 & 2 & 9 & ? & 0.70 & Tingei \\
\hline 21 & 6 & 12 & 6 & 1.00 & Tinge \\
\hline 22 & 5 & 11 & 6 & 0.86 & Tinge \\
\hline 23 & 6 & 10 & 4 & 0.67 & Sedrez \\
\hline 24 & 2 & 6 & 4 & 0.40 & Sadrate \\
\hline 25 & 9 & 12 & 3 & 1.00 & Tinge \\
\hline 26 & 3 & 11 & 8 & 0.89 & Ting \\
\hline 27 & 3 & 11 & 8 & 0.89 & Tinge \\
\hline 28 & 6 & 11 & 5 & 0.83 & Tinge \\
\hline 29 & 7 & 10 & 3 & 0.60 & Sedurg \\
\hline 30 & 3 & 11 & 8 & 0.89 & Tinge \\
\hline 31 & 5 & 10 & 5 & 0.71 & Tingei \\
\hline 32 & 5 & 11 & 6 & 0.86 & Tingei \\
\hline 33 & 6 & 12 & 6 & 1.00 & Tinge \\
\hline 34 & 1 & 10 & 9 & 0.82 & Tinge \\
\hline 35 & 4 & 11 & 7 & 0.88 & Tinge \\
\hline Jualuh & 149 & 367 & 218 & \multirow{5}{*}{0.81} & \multirow{5}{*}{ Ting } \\
\hline $\begin{array}{l}\text { Juglah Deserta } \\
\text { Didik }\end{array}$ & 35 & 35 & 35 & & \\
\hline $\begin{array}{c}\text { Didik } \\
\text { Rata-ran }\end{array}$ & 426 & 10.49 & 623 & & \\
\hline Skor Tertesur & 9 & 12 & 9 & & \\
\hline Skor Tekakil & 1 & 6 & 3 & & \\
\hline
\end{tabular}

Berdasarkan tabel 6 di atas dapat dilihat bahw aktivitas guru selama pembelajaran menggunakan model pembelajaran kooperatif tipe TPS dapat meningkatkan nilai rata-rata pada kels eksperimen. Pada table $4.1 \mathrm{di}$ atas, persentase aktivitas siswa pada kelas kontrol sebesar 69,69\%. Persentase ini masih berada di bawah indikator keberhasilan yang telah peneliti tentukan yaitu sebesar $\geq 80 \%$. Pada siklus pretes ini aspek yang masih sangat kurang yaitu dalam hal menghargai pendapat yang disampaikan oleh temannya. Hal ini disebabkan oleh rasa egois yang masih banyak muncul pada diri siswa. Karena persentase ini masih belum mencapai indikator keberhasilan yang telah ditentukan, maka penelitian ini dilanjutkan ke siklus eksperimen. Pada siklus postes, hasil perhitungan persentase aktivitas siswa sebesar 80,3\%. Hasil ini telah mencapai indikator keberhasilan, namun hanya selisih sedikit dari indikator yang telah ditentukan peneliti. Untuk lebih menguatkan hasil peneli

Seorang yang berpikir kritis bisa menanyakan pertanyaan yang tepat, mengumpulkan informasi yang relevan, efisien dan kreatif sehingga memungkinkan seseorang untuk menjadi lebih baik dan sukses dalam kehidupan (Chell, 2013). Teori belajar tersebut berkenaan dengan kesiapan anak untuk belajar, yang dikemas dalam tahap perkembangan intelektual dari lahir hingga dewasa. Setiap tahap perkembangan intelektual yang dimaksud dilengkapi dengan ciri-ciri tertentu dalam mengkonstruksi ilmu pengetahuan. Misalnya, pada tahap sensori motor anak berpikir melalui gerakan atau perbuatan .Pemahaman saat menerima informasi dapat mendorong munculnya ide dan menaikkan struktur kognitif yang memungkinkan peserta didik berpikir kembali mengenai ide sebelumnya.

\section{Tabel 7}

\section{Rekapitulasi Hasil Postest Kelas Eksperimen}

\begin{tabular}{ccc}
\hline $\begin{array}{c}\text { Kriteria Kemampuan } \\
\text { Berpikir Kritis }\end{array}$ & Frekuensi & Persentase \\
\hline Sangat Rendah & 1 & $2.86 \%$ \\
Rendah & 0 & $0.00 \%$ \\
Sedang & 3 & $8.57 \%$ \\
Tinggi & 14 & $40.00 \%$ \\
Sangat Tinggi & 17 & $48.57 \%$ \\
\hline Jumlah & 35 & $100 \%$ \\
\hline
\end{tabular}

Berdasarkan tabel 7, dapat dilihat mayoritas kemampuan berfikir kritis yakni termasuk dalam kategori sangat tinggi. Yang di tunjukkan dengan 17 siswa atau $48.57 \%$ dan minoritas kemampuan berfikir kritis sangat rendah. Terbukti implikasi dalam pembelajaran adalah bahwa siswa dan guru akan melakukan empat tidakan tersebut, untuk lebih jelasnya dipaparkan seperti :1)Mengembangkan berpikir kritis karakteristik dan perilaku. Ketika eseorang memiliki berpikir kritis karakteristik, keterampilan di kalangan lainnya datang dengan mudah.2)Memperoleh pengetahuan teoritis dan pengalaman, serta keterampilan intelektual. 3)Keuntungan keterampilan interpersonal. Jika Anda tidak bisa bergaul dengan orang lain, Anda akan mungkin untuk berpikir kritis.

Menurut Dike pembelajaran melalui think pair share kemampuan berpikir kritis terdapat 3 aspek yakni definisi dan klarifikasi masalah, menilai dan mengolah informasi berhubungan dengan masalah, solusi masalah atau membuat kesimpulan dan memecahkan. Melalui model ini diharapkan kemampuan berpikir kritis peserta didik dapat meningkat sehingga nantinya peserta didik memiliki keterampilan dan kecakapan dalam hidup.(Marketing, Relation, Keputusan, \& Wisata, 2000) Hasil pengembangan kemampuan berpikir kritis akan meningkatkan peserta didik untuk mampu mengakses informasi dan definisi masalah berdasarkan fakta dan data akurat. Selain itu, peserta 
didik juga akan mampu menyusun dan merumuskan pertanyaan secara tepat, berani mengungkapkan ide, gagasan serta menghargai perbedaan pendapat (Utama et al., 2016). Melalui berpikir kritis peserta didik akan memiliki kesadaran kognitif sosial dan berpartisipasi aktif dalam bermasyarakat (Nuryanti, 2004).

\section{KESIMPULAN \& REKOMENDASI}

Hasil pengujian gambaran pretest dan posttest kemampuan berpikir kritis siswa kelas kontrol dengan menggunakan metode konvensional disimpulkan terdapat perbedaan signifikan dalam kemampuan berpikir kritis peserta didik sebelum dan sesudah menggunakan metode konvensional di kelas kontrol.

Hasil pengujian gambaran pretest dan posttest kemampuan berpikir kritis siswa kelas eksperimen dengan menggunakan metode think pair share disimpulkan terdapat perbedaan signifikan dalam kemampuan berpikir kritis peserta didik sebelum dan sesudah menggunakan metode think pair share di kelas eksperimen. Pembelajaran yang dilaksanakan dengan metode TPS menekankan penyampaian materi yang dilakukan oleh guru dalam kelas yang dilanjutkan dengan kerja kelompok siswa. Siswa yang belajar dengan metode think pair share. mengalami peningkatan rata-rata skor kemampuan berpikir kritis lebih tinggi dibanding siswa yang belajar dengan metode konvensional. Proses pembelajaran dengan metode think pair share ini juga sesuai dengan paradigma pembelajaran konstruktivistik yang menekankan pengembangan kemampuan siswa dalam menemukan jawaban atas permasalahan yang sedang dikaji (Series \& Science, 2017).

Metode cooperative learning baik untuk digunakan sesuai dengan hasil dari penelitian tentang penggunaan metode cooperative learning antara lain: mendukung pembelajaran siswa dan pencapaian akademik, meningkatkan daya ingat siswa, meningkatkan kepuasan siswa dengan pengalaman belajar mereka, membantu siswa megembangkan kemampuan dalam berkomunikasi secara lisan, mengembangkan kemampuan sosialisasi siswa, meningkatkan kepercayaan diri siswa dan membantu siswa untuk meningkatkan hubungan persaingan yang positif.(Indonesia, Tarmedi, Indonesia, \& Menggunakan, 2017)

\section{DAFTAR PUSTAKA}

Ali, S. A. (2016). Critical Thinking in the Information Age: Helping Students Find and Evaluate Scientific Information. Teaching Innovation Projects, 6(1).
Alpusari, M., \& Putra, A. (2015). The Application of Cooperative Learning Think Pair Share ( TPS ) Model to Increase the Process Science Skills in Class IV Elementry School Number 81 Pekanbaru City, 4(4), 2805-2808.

Arikunto, S. (2006). Prosedur Penelitian Suatu Pendekatan Praktek. Jakarta: PT. Rineka Cipta.

Arsal, Z. (2015). The effects of microteaching on the critical thinking dispositions of pre-service teachers. Australian Journal of Teacher Education, 40(3), 140-153. https://doi.org/10.14221/ajte.2014v40n3.9

Ayad, A. (2010). Critical thinking and business process improvement. Journal of Management Development, 29, 556-564. https://doi.org/10.1108/02621711011046521

Bahr, N. (2010). Thinking Critically about Critical Thinking in Higher Education, 4(2).

Baron, J. (1993). Why Teach Thinking?-An Essay. Applied Psychology, 42(3), 191-214. https://doi.org/10.1111/j.14640597.1993.tb00731.x

Bashir, I., \& Madhavaiah, C. (2015). Consumer attitude and behavioural intention towards Internet banking adoption in India. Journal of Indian Business Research, 7(1), 67-102. https://doi.org/10.1108/JIBR-02-2014-0013

Baudin, V., \& Villemur, T. (2009). Student centered distance learning experiments over a communication and collaboration platform. Interactive Technology and Smart Education, 6(1), 60-75. https://doi.org/10.1108/17415650910965209

Baumfield, V., \& Oberski, I. (1998). What do teachers think about thinking skills? Quality Assurance in Education, 6(1), 44-51. https://doi.org/10.1108/09684889810200386

Bayat, Ö. (2004). The effects of cooperative learning activities on student attitudes towards English reading courses and cooperative learning, (July).

Bustami, Y., \& Corebima, A. D. (2017). The Effect of Jirqa Learning Strategy on Critical Thinking Skills of Multiethnic Students in Higher Education, Indonesia, 4(3), 13-22.

Chell, E. (2013). Review of skill and the entrepreneurial process. International Journal of Entrepreneurial Behaviour \& Research, 19, 6-31. https://doi.org/10.1108/13552551311299233

Decd, S. F. O. R. (2017). LEARNING STRATEGY FOR DECD PRESCHOOL TO YEAR 12.

Fatmawati, H. (2014). POKOK BAHASAN PERSAMAAN KUADRAT ( Penelitian pada Siswa Kelas X SMK Muhammadiyah 1 Sragen Tahun Pelajaran 2013 / 2014 ), 2(9), 911-922. 
Fax, P. (2012). Critical Thinking Indicators ( CTIs ), $1-10$.

Goodfellow, L. M. (1995). Cooperative Learning Strategies. Nurse Educator, 20(4), 26-29. https://doi.org/10.1097/00006223-19950700000010

Haghparast, M., Nasaruddin, F. H., \& Abdullah, N. (2014). Cultivating Critical Thinking Through E-learning Environment and Tools: A Review. Procedia - Social and Behavioral Sciences, 129 , 527-535. https://doi.org/10.1016/j.sbspro.2014.03.710

Indonesia, U. P., Tarmedi, E., Indonesia, U. P., \& Menggunakan, K. (2017). Pengaruh perbedaan individu terhadap keputusan menggunakan sistem operasi linux, 1(1), 174-180.

Kagan, R., \& Knopf, A. A. (2003). OF PARADISE.

Kagan, S. (n.d.). The Structural Approach to Cooperative Learning.

King, F. J., Goodson, L., \& Rohani, F. (1998). Higher Order Thinking Skills. Publication of the Educational Services Program, Now Known as the Center for Advancement of Learning and Assessment. Obtido de: Www.cala.fsu.edu, 1$176 . \quad$ Retrieved from http://www.cala.fsu.edu/files/higher_order_thin king_skills.pdf

Li, M. P., \& Lam, B. H. (2013). Cooperative Learning. The Hong Kong Institute of Education, 1-33.

Madan, K., \& Yadav, R. (2016). Behavioural intention to adopt mobile wallet: a developing country perspective. Journal of Indian Business Research, 8(3), 227-244. https://doi.org/10.1108/JIBR-10-2015-0112

Marketing, P., Relation, P., Keputusan, T., \& Wisata, O. (2000). ( Survei Pada Wisatawan Nusantara Pasca Tsunami ) Bambang Widjajanta Ani Siswanti, 65-76.

Meiramova, S., Cooperation, I., Education, M., \& Centre, D. (2017). APPLICATIONS OF CRITICAL THINKING RESEARCH : FOREIGN LANGUAGE TEACHING IN AN INTERCULTURAL CONTEXT, 7(1), 24-36.

Nuryanti, B. L. (2004). MODEL PEMBELAJARAN E-LEARNING MELALUI HOMEPAGE SEBAGAI MEDIA PEMBELAJARAN

\section{SEHINGGA DIHARAPKAN DAPAT MENINGKATKAN MINAT DAN KREATIVITAS SISWA.}

Plan, S. (2018). For a Better Tomorrow.

Portal, S. (2017). Atlantic Technical High School Critical Thinking \& Study Skills Syllabus.

Risnanosanti. (2009). Seminar Nasional Matematika dan Pendidikan Matematika Jurusan Pendidikan Matematika FMIPA UNY, 5 Desember 2009. Penggunaan Pembelajaran Inkuiri Dalam Mengembangkan Kemampuan Berpikir Kreatif Siswa Sma Di Kota Bengkulu, 978-979.

Sanjaya Wina. (2006). Strategi Pembelajaran. Jakarta: Kencana Prenada Media Group.

Series, I. O. P. C., \& Science, M. (2017). Improving the Competitiveness of UPI as a ResearchBased Teaching Improving the Competitiveness of UPI as a Research-Based Teaching University. https://doi.org/10.1088/17426596/755/1/011001

Tarmedi, E., \& Asri, P. N. (n.d.). PENGARUH PERCEIVED QUALITY DARI BRAND EQUITY TERHADAP, 35-49.

Thahara, I. P., Indonesia, U. P., Mulyadi, H., Indonesia, U. P., \& Indonesia, U. P. (2016). EFEKTIVITAS MODEL PROBLEM BASED LEARNING DALAM MENINGKATKAN KEMAMPUAN BERPIKIR KRITIS PESERTA DIDIK PADA KELAS BISNIS DAN, 1(2), 70-74.

Tiruneh, D. T., Verburgh, A., \& Elen, J. (2014). Effectiveness of Critical Thinking Instruction in Higher Education: A Systematic Review of Intervention Studies. Higher Education Studies, 4(1), 1-17. https://doi.org/10.5539/hes.v4n1p1

Utama, R. D. H., S, B. L. N., \& Sutarni, N. (2016). Entrepreneurship Intention to Trigger Entrepreneurship Orientation, 15, 706-710.

Wibowo, L. A. (2006). PENGARUH METODE COOPERATIVE LEARNING TEKNIK JIGSAW, 520-528. 